\title{
Risk Retirement-Decreasing Uncertainty and Informing Consenting Processes for Marine Renewable Energy Development
}

\author{
Andrea E. Copping * (D), Mikaela C. Freeman, Alicia M. Gorton ${ }^{(1)}$ and Lenaïg G. Hemery \\ Coastal Division, Pacific Northwest National Laboratory, Seattle, WA 98019, USA; \\ mikaela.freeman@pnnl.gov (M.C.F.); alicia.gorton@pnnl.gov (A.M.G.); lenaig.hemery@pnnl.gov (L.G.H.) \\ * Correspondence: andrea.copping@pnnl.gov
}

Received: 1 February 2020; Accepted: 1 March 2020; Published: 4 March 2020

\begin{abstract}
Marine renewable energy (MRE) is under development in many coastal nations, adding to the portfolio of low carbon energy sources that power national electricity grids as well as off-grid uses in isolated areas and at sea. Progress in establishing the MRE industry, largely wave and tidal energy, has been slowed in part due to uncertainty about environmental risks of these devices, including harm to marine animals and habitats, and the associated concerns of regulators and stakeholders. A process for risk retirement was developed to organize and apply knowledge in a strategic manner that considered whether specific environmental effects are likely to cause harm. The risk retirement process was tested against two key MRE stressors: effects of underwater noise from operational MRE devices on marine animals, and effects of electromagnetic fields from MRE electrical export cables on marine animals. The effects of installation of MRE devices were not accounted for in this analysis. Applying the risk retirement process could decrease the need for costly investigations of each potential effect at every new MRE project site and help move the industry beyond current barriers.
\end{abstract}

Keywords: marine renewable energy; risk retirement; environmental effects; consenting/permitting

\section{Introduction}

The need to reduce global demand for fossil fuels, as well as increasing concerns about supplying the energy needs of isolated communities, support the need for a varied portfolio of renewable energy sources [1]. Marine renewable energy (MRE) can be a part of the solution for mitigating climate change and safeguarding energy security for national electricity grids and off-grid applications [2,3]. As of 2018, MRE contributed less than $0.02 \%$ to the total global renewable energy capacity, much of which is accounted for by the tidal barrages of France and South Korea [4].

The slow pace of MRE growth can be explained by significant technical challenges, including the need to design systems that can withstand the harsh ocean environment, engineering challenges to optimize energy capture, and having difficulties in securing financing for a new industry $[5,6]$. In addition, the process of obtaining permission to deploy and operate MRE devices has often been long and expensive for the proponents $[2,7,8]$. This is largely based on significant uncertainty surrounding the potential effects of these systems on the marine environment [3,9], as well as uncertainty surrounding specifics of the consenting/permitting pathway. The regulatory processes that allow for the deployment of MRE are variously called "consenting" and "permitting" in different nations. For the purposes of this paper, the term consenting will be used.

Frequently, little information is publicly available about potential environmental effects at a site projected for an MRE development; regulators expect developers to undertake comprehensive baseline and post-installation monitoring surveys to fill in these information gaps $[2,7,10]$. Collecting 
observations and monitoring data in high-energy portions of the marine environment suitable for MRE development is particularly challenging [2,3]. The assessment of cumulative effects of MRE development with other anthropogenic activities also concerns regulators and other stakeholders [11]. Effects of installation of MRE devices include potential disturbances of marine animals from construction activities such as piling [12], as well as the presence of vessels operating at various speeds between shore and the project site that may also result in collisions causing injury or death to marine mammals [13]. The risk retirement process presented in this paper does not address installation risks, as these closely resemble offshore construction activities from other industries and are relatively well understood [14,15].

In many cases, faced by the uncertainty of whether MRE devices may pose an unacceptable risk to marine animals or the habitats that support them, regulators rely on the precautionary principle to justify extensive requests for data collection, and may deny the necessary consents and licenses to operate [11].

The concept of risk is ingrained in environmental assessment and management within the regulatory regimes of most nations [10]. Risk is often defined as the intersection of the likelihood or probability of an event occurring, and the consequences of the event if it were to occur [11]. Risk is often expressed in terms of impacts or effects [16], with impacts considered to be deleterious changes to marine animal populations or habitats, whereas effects are measurable but not necessarily important or critical to the health of the populations or environments. Uncertainties around potential environmental risks need to be understood, acknowledged, and managed comparably to other maritime industries for these risks to be reduced and the MRE industry to move forward [3].

Despite these potential risks and challenges, increasing numbers of MRE installations have been consented, deployed, and operated in various parts of the world since 2000, either at consented test centers or at specific project sites. Although most deployments have consisted of one or two devices, the push towards commercial arrays has begun with the deployment of the MeyGen array north of the Scottish mainland [17]. These deployments were achieved under a diversity of consenting schemes and frameworks that have generated scientific knowledge to address the uncertainties surrounding potential effects while assuring environmental protection [2].

The scheme that has consented the greatest number of deployments was developed in Scotland and is known as the "survey, deploy, monitor" approach. It relies on gathering baseline information and anticipation of post-installation effects, which can be verified by the collection of monitoring data $[10,18]$. This approach has proved most successful when adequate baseline data exist [2]. The Rochdale Envelope approach, mainly employed in the United Kingdom, is a more flexible and evolutive process used in conjunction with environmental impacts assessments (EIAs), allowing licenses to be granted when some technological aspects of a project are not fully defined at the time of application $[2,19,20]$. Application of the adaptive management approach, which allows for evaluation and adjustments of monitoring requirements as the deployment and operation continues, has provided confidence to regulators in consenting MRE projects and flexibility to regulators and developers to learn as they go $[2,21]$.

Other frameworks have prioritized risks and evaluated the severity of the consequences:

(1) The bow tie method provides a broadly applicable method of connecting probability and consequences of risk [22].

(2) Hierarchical methods allow for triage of risks to effectively filter out low risks, allowing a focus on medium-to-high risks [23].

(3) The Environmental Risk Evaluation System (ERES) was developed for the marine energy and offshore wind industry as a process to inform developers, regulators, and stakeholders on the potential environmental impacts of a project [24,25].

(4) The Impact Assessment Tool was developed for Marine Scotland to provide preliminary assessments of potential environmental risks associated with MRE projects [26].

(5) Methods for considering cumulative effects assessments consider the potential for cumulative risks [27-29]. 
(6) The Cumulative Effects of Offshore activities (CUMULEO) framework seeks to identify the potential for cumulative effects, including those associated with other industries and climate change [30].

The MRE industry will move forward more rapidly if the level of uncertainty around potential effects is reduced for single devices [31]. Following this effort, there will be a need to focus on future effects of larger arrays, as well as assessments and monitoring for higher level risks [32]. In the past decade, knowledge of potential effects of MRE has increased rapidly, and uncertainty has decreased, with strong indications that most effects are unlikely to be significant at the scale of single devices or small arrays [3]. On the basis of the current level of knowledge, the risk of certain interactions of MRE devices with the marine environment might be "retired" in the case of single devices or small arrays [3]. In this context, the concept of risk retirement will allow regulators to rely on existing knowledge to inform new projects, to require data collection around projects as a means to ensure that the existing knowledge base applies in the project location, and to contribute to and validate numerical models that describe the interactions [31]. This process of risk retirement would facilitate the consenting process for regulators, reduce the time and financial burden on developers, add to the existing knowledge base, and promote public understanding and acceptance of MRE projects [3]. Several interactions of MRE systems and the marine environment (stressor-receptor interactions [16]) are sufficiently well-informed to warrant risk retirement for small numbers of devices, notably:

(1) Effects of underwater noise generated by MRE devices on marine mammals and fish;

(2) Electromagnetic fields (EMF) emitted by export power cables on certain marine species;

(3) Changes in benthic and pelagic habitats; and

(4) Changes to the movement of water and sediments as a result of MRE operation.

For other stressor-receptor interactions, notably the risk to marine animals from collisions with moving parts of MRE systems such as turbine blades, there is not yet sufficient information to consider risk retirement [3]. If interactions that are not causing harm to the environment were to be retired for single devices and small arrays, then researchers, regulators, and developers could focus their efforts on understanding and preventing the interactions for which there remains a high level of uncertainty [31].

The term "risk retirement" has been used within the MRE community and other technology-focused development programs such as geotechnical risk management to delineate circumstances where key stressor-receptor interactions are sufficiently understood in order to alleviate the need to carry out detailed investigations for each proposed project [33]. To date, no detailed methodology for determining when an MRE risk might be "retired" has been described, nor has the evidence needed to support such a claim been identified, or a trigger for revisiting retired risks discussed should the existing information prove insufficient, particularly as larger commercial arrays are proposed.

A risk retirement pathway was developed for the Ocean Energy Systems (OES)-Environmental collaborative to explore the process of retiring specific stressor-receptor interactions to facilitate consenting applications. OES-Environmental (formerly known as Annex IV) is a collaborative initiative of 15 nations under the International Energy Agency Oceans Energy Systems whose purpose is to understand MRE environmental effects that affect consenting [34]. This paper details the risk retirement pathway, with application to risks of underwater noise and EMF.

\section{Materials and Methods}

The risk retirement pathway was developed for OES-Environmental to support a description of stressor-receptor interactions of importance for consenting, provide a framework for collating evidence that allows experts to evaluate whether a risk can be retired, and organize consistent application of datasets from consented projects to inform new project applications.

For the concept and practice of risk retirement to succeed in supporting responsible and timely consenting, there is a need for key stakeholders in the MRE development process to be engaged and ultimately accepting of the process. 


\subsection{Pathway to Retiring Risk}

The risk retirement pathway (Figure 1) consists of sequential steps or stages that allow the user (for example, researcher, device or project developer, or regulator) to determine the level of risk associated with a proposed MRE project, on the basis of a description of the project. This includes the number and type of MRE devices, the environment into which the devices will be deployed, and any specific attributes of the operation that might cause injury or stress to marine animals or the marine environment. The stages compare the likely risk to what is known about particular stressor-receptor interactions, whether additional data collection at the site is needed to determine the likely risk, and whether and how mitigation should be applied. The comparative risks are drawn from a review of studies and monitoring programs [3,31]. Ultimately, the risk retirement pathway might suggest that risk from a proposed project cannot be retired or mitigated, and that redesign or abandonment of the project is necessary. At each step in the risk retirement pathway, there is the opportunity to determine if the risk can be retired. A more detailed account of the process and the requirements for each stage can be found in [35] and in [36]. As part of the risk retirement process, data and information are applied at each stage to inform the process and to create feedback loops within the process. The application of data and information is indicated as dotted lines and arrows in Figure 1; these are further described in the following section on data transferability. More technical details about the risk retirement process can be found in the Supplementary Material Section.

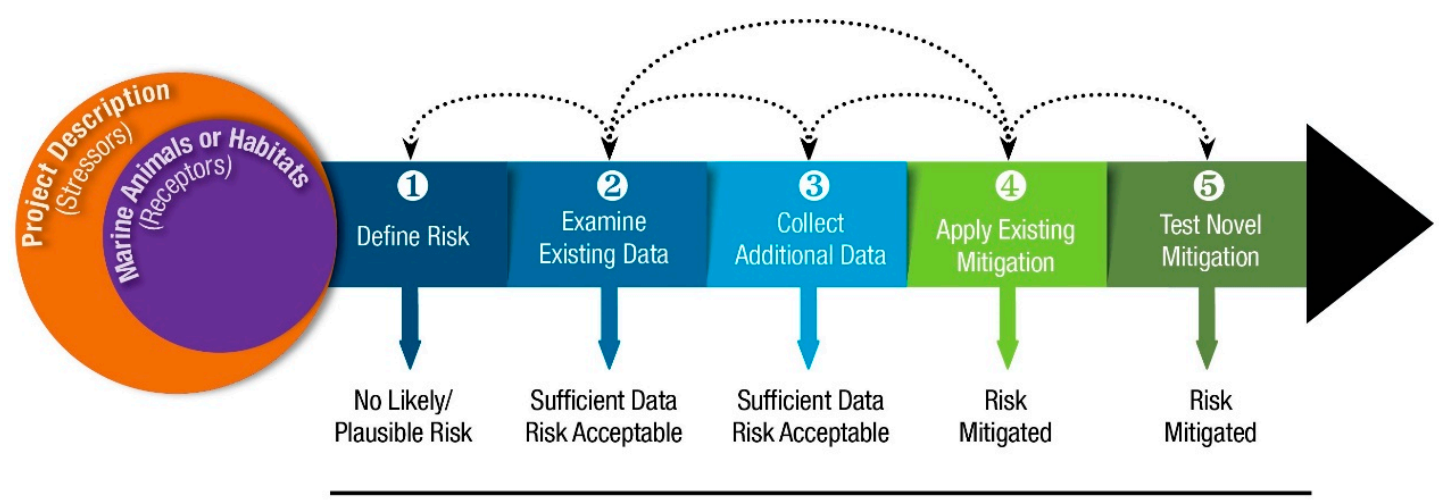

R I S K R R E T I R E M E N T

Figure 1. Risk retirement pathway. Starting from the left, the project must be described (orange circle), followed by identifying the presence of animals and habitats that may be at risk (purple circle). Five stage gates follow that allow retirement of risk at each stage. The dotted lines and arrows above the pathway indicate the application of datasets from previously consented marine renewable energy (MRE) projects and research studies that inform each step in the process and create feedback loops (data transferability).

\subsection{Data Transferability}

Inherent in the process of risk retirement is the availability of sufficient data and information to support a common understanding of the potential environmental risks from MRE devices. This process, called data transferability, is a concept developed under OES-Environmental to support the risk retirement pathway by examining and cataloging datasets collected from consented MRE projects and associated research projects. The datasets are selected such that they will inform the decision processes of regulators for future consenting actions. Here, the term "data" is used to include raw data and quality-assured data, as well as compiled and analyzed data, reports, and lessons learned. As shown in Figure 2, the data transferability process consists of four components: (1) data transferability framework, (2) data collection consistency, (3) data discoverability, and (4) best management practices. Detailed information on the application of the data transferability process including the online searchable matrix of datasets (Monitoring Datasets Discoverability Matrix) and the assessment of comparable 
data collection methods and analyses efforts (Data Collection Consistency Table) can be found in [37], as well as in the Supplementary Material Section.

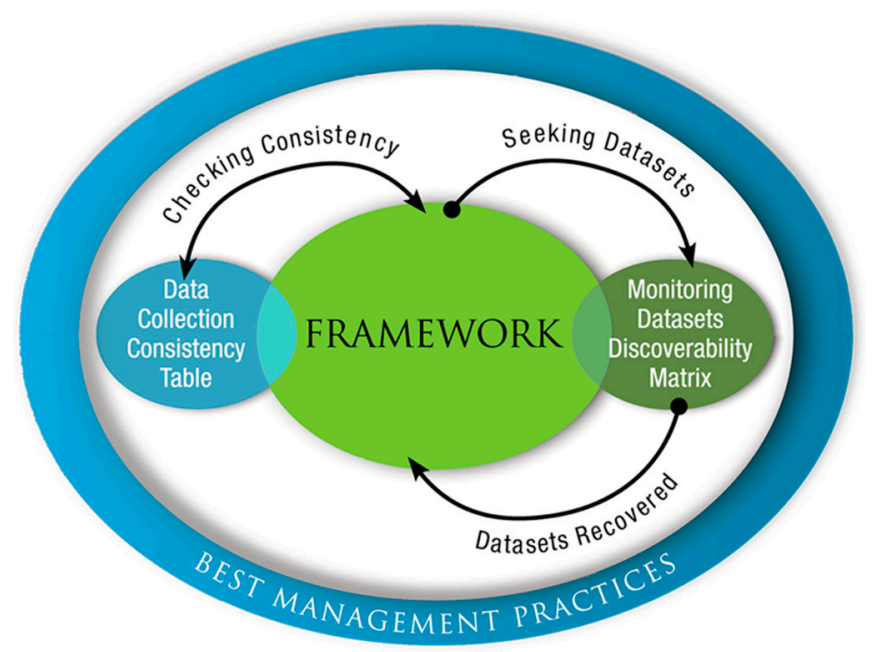

Figure 2. Data transferability process. Regulators and other stakeholders can evaluate datasets from consented projects that are sufficiently similar to inform applications for new projects. They can also check that the data collections methods are compatible, and retrieve those datasets for use in determining consenting needs.

\subsection{Assembling the Risk Retirement Evidence Base for Underwater Noise and EMF}

Until the risk retirement pathway is applied to a stressor-receptor interaction of importance to MRE consenting, it remains a theoretical construct. In order to test the process and support advancement of consenting devices, two stressors were chosen for cataloging and evaluating evidence: underwater noise and EMF. Recent literature related to interactions of these two stressors with the marine environment were reviewed and assembled to create an evidence base against which the process of risk retirement could be tested. This assessment is aimed at determining whether these risks could be considered as retired for a small number of MRE devices. The evidence base was drawn from review compilations such as $[3,34,38]$; from extensive literature review; from assessments of existing consents and licenses as well as monitoring reports for MRE deployments and operations throughout the OES-Environmental nations; and from discussions with researchers, MRE developers, regulators, and consultants actively involved in the measurement and assessment of MRE effects. The evidence base was assembled and applied to a series of hypothetical MRE projects against which the existing information could be tested. Three expert workshops held in 2019 were used as forums to test the evidence base, to gather feedback on the risk retirement process, and to provide input on additional information needs to support risk retirement.

\subsection{Stakeholder Outreach and Engagement}

The development of the risk retirement pathway and subsequent evaluation of evidence bases for priority stressor-receptor interactions depend heavily on a robust stakeholder outreach and engagement process. An initial survey of regulators in the United States was carried out to determine the level of knowledge among state and federal regulators, as well as to understand their appetite for management strategies that included phased development of MRE projects, application of adaptive management, application of data from other jurisdictions to support their consenting decisions, and risk retirement [39]. Similar surveys are being completed for the other OES-Environmental nations. A series of workshops and online forums engaged U.S. regulators throughout the development of the data transferability and risk retirement processes, and a public webinar was held to further engage stakeholders beyond the regulatory community, with an emphasis on MRE developers, their consultants, and researchers. 


\section{Results}

The evidence bases gathered to understand if risk of underwater noise from MRE devices and EMF emissions from submarine cables might be retired for small numbers of devices are presented separately here.

\subsection{Underwater Noise}

Underwater noise emitted from MRE devices may affect marine mammals and fish by causing changes in behavior including avoidance or attraction to the MRE device or may mask critical biological systems used for underwater communication and navigation [40,41]. In extreme cases, underwater noise may cause physical harm to marine animals through temporary or permanent hearing shifts or tissue damage. The ability of marine animals to detect sound from MRE devices depends on species-specific characteristics and the frequency and amplitude of the emitted noise [42]. Measurements of underwater noise from MRE devices have been collected in a number of locations, as summarized in Table 1.

Regulatory thresholds for underwater noise have been developed in the United States for marine mammals [43], and guidelines have been put forth for thresholds for fish [44] and are shown in Table 2, for comparison to projects shown in Table 1. The application of these thresholds to underwater noise emitted from wave energy converters (WECs) and turbines operating in tidal environments and rivers creates a benchmark against which regulators can evaluate the likely risk to these important living resources and environments. In addition, an international group (TC114) under the International Electrochemical Commission (IEC) has developed standards for measuring underwater noise emitted from MRE devices (IEC 62600-40 [45]). The combination of regulatory thresholds and accepted standard protocols for measurements provide a background against which the risk from underwater noise from MRE devices can be evaluated. The underwater noise emitted from each MRE device is noted in Table 2 in relation to the U.S. regulatory threshold for underwater sound $[43,44]$.

MRE devices may not be detectable above ambient noise levels and other anthropogenic sources in the vicinity of an MRE deployment, as measurements at several of the MRE project sites demonstrate, including the Columbia Power WEC [46], the Schottel Strangford Lough turbine [47], and perhaps the Wello WEC [48]. Although some behavioral responses occur as marine animals swim near devices, there is little evidence that effects of underwater noise from a single device create a substantial disturbance or cause injury to marine animals, such as those at the WaveRoller site [49], the Paimpol Brehat OpenHydro site [50], and the Minesto Strangford Lough site [51]. The relatively short timeframes over which marine animals have been observed to swim near devices supports the lack of disturbance by MRE device noise outputs; however, effects of long-term exposure to lower amplitudes of sound are not accounted for. It is also clear that the noise emitted from an MRE device can be gauged over the life of the device, as acoustic instruments are routinely deployed to evaluate the health of the device, as demonstrated by the rapid evaluation by Verdant Power RITE of failing turbines [52]. Similarly, acoustic monitoring of the Fred. Olsen Bolt Lifesaver WEC pinpointed the additional noise generated as originating from the anchor chain, rather than the device itself [53].

\subsection{Electromagnetic Fields (EMF)}

Electromagnetic field signatures emitted from MRE devices, power cables, underwater substations, or transformers may affect marine animals in the vicinity of the power source through changes in behavior, which might include avoidance/attraction to the cable or another energy source [54], and perhaps changes in hunting or feeding patterns [55]. In addition, electrical and magnetic fields have been shown to cause physiological and developmental changes in certain species [56]. For these animals that are guided by the earth's magnetic field for migration and other movement patterns, it has been hypothesized that additional EMF in the environment may alter the animals' ability to detect and respond to the natural field [57]. In order to respond to EMF, animals must possess electro- 
or magneto-receptors; these animals include certain species of elasmobranchs (sharks, skates, rays), some benthic and perhaps pelagic crustaceans and mollusks, sea turtles, and some groups of fish [57]. Measurements of effects of EMF from MRE devices have been acquired in few locations, meaning that the evidence base is largely associated with laboratory and field research information, as summarized in Table 3.

At this early stage in the development of the MRE industry, only a few devices have been cabled to shore, and few have carried significant amounts of power. In lieu of measuring active power export cables and other electrified infrastructure, a series of research studies have used Helmholz coils in the laboratory to create artificial EMF and measure effects of an assortment of energized and surrogate cables in the ocean [58]. There are significant challenges in measuring EMF from undersea cables in the marine environment, due to the nature of the interaction of the electrical field with seawater [59], as well as the presence of other large metallic structures in coastal waters [59].

No regulatory thresholds or guidance for allowable emissions of EMF in the marine environment have been found through indepth literature reviews and discussions with subject matter experts, which increases the challenge in determining if MRE devices are likely to cause harm to marine animals.

Laboratory and field studies have noted that electro- and magneto-sensitive species have shown clear awareness of the presence of EMF, but do not appear to significantly change their behavior, including several species of crustaceans under laboratory conditions [60,61]. Laboratory studies have shown some developmental delays and changes in physiology among fish and crustaceans $[60,62]$. Field studies designed to determine whether EMF emissions might cause a barrier effect-preventing animals from reaching their preferred habitats or feeding grounds-found no evidence to support this hypothesis in European eels [54], in two commercial species of crab in the United States [63], or in several species of elasmobranchs or American lobster [64]. Laboratory and field studies on effects of EMF on freshwater fish species indicated that even large EMF do not appear to cause deleterious effects $[65,66]$. Other field studies were unable to detect responses on local marine animals $[59,67-70]$, or found that responses by electro-sensitive elasmobranchs did not change behavior significantly [55].

\subsection{Evaluating Risk Retirement}

Experts and practitioners involved with MRE were asked at three international workshops to examine the process of risk retirement, review the evidence base for underwater noise and EMF, and discuss whether risk retirement was possible for these two stressors for small numbers of MRE devices. The three workshops brought together the experts and practitioners in three countries (Italy, the United States, Australia) during 2019, and involved 81 MRE experts from 11 countries (Australia, Canada, France, Germany, Italy, Korea, Netherlands, Portugal, Sweden, the United Kingdom, the United States).

During the workshops, the current state of knowledge on underwater noise and EMF (Tables 1 and 3) was presented to the participants. Then, hypothetical examples (Figure 3) were introduced to walk the participants through the successive stages of the risk retirement pathway and discuss the feasibility of the approach. Overall, the workshop participants found the risk retirement pathway intuitive and easy to navigate. Participants at the workshop in Australia particularly felt it could fit with the Australian environmental regulatory process. 
Table 1. Selected studies from the evidence base for MRE underwater noise effects on marine animals. These outcomes are based on deployments of single devices or small arrays of tidal or river turbines, or wave energy converters (WECs), as well as selected research studies.

\begin{tabular}{|c|c|c|c|c|c|}
\hline Project & Location & Device & Noise Measurements & Conclusion & $\begin{array}{l}\text { Relation to U.S. } \\
\text { Underwater } \\
\text { Sound Threshold }\end{array}$ \\
\hline $\begin{array}{c}\text { Verdant Power } \\
\text { Roosevelt Island Tidal } \\
\text { Energy Project (RITE) } \\
(2006-2008)[52]\end{array}$ & $\begin{array}{l}\text { New York, } \\
\text { United States }\end{array}$ & $\begin{array}{c}\text { Tidal } \\
\text { turbine array }\end{array}$ & $\begin{array}{l}\text { Operational noise of the array, which included } \\
\text { six bottom mounted turbines, was up to } 145 \text { re } \\
\qquad 1 \mu \mathrm{Pa} \text { at } 1 \mathrm{~m} \text { from the array. }\end{array}$ & $\begin{array}{l}\text { More noise was output than expected due to a } \\
\text { broken blade on one turbine and another } \\
\text { failing turbine. }\end{array}$ & $\begin{array}{l}\text { Remains under } \\
\text { threshold for } \\
\text { broadband sound }\end{array}$ \\
\hline $\begin{array}{l}\text { Columbia Power } \\
\text { Technologies SeaRay } \\
\text { (2011-2012) [46] }\end{array}$ & $\begin{array}{l}\text { Washington, } \\
\text { United States }\end{array}$ & WEC & $\begin{array}{l}\text { Operational noise of one-seventh scale wave } \\
\text { buoy varied from background noise levels at } \\
116 \mathrm{~dB} \text { re } 1 \mu \mathrm{Pa}^{2} \text { to intermittent peaks at } \\
126 \mathrm{~dB} \text { re } 1 \mu \mathrm{Pa}^{2} \text {. }\end{array}$ & $\begin{array}{l}\text { Sound was not detectable above ambient noise } \\
\text { levels. With the acoustic signature of the SeaRay, } \\
\text { which is a broadband source, the noise levels were } \\
\text { subject to masking by stronger sources in its vicinity. }\end{array}$ & N/A \\
\hline $\begin{array}{l}\text { Research study for } \\
\text { OpenHydro (device } \\
\text { never deployed) [71] }\end{array}$ & $\begin{array}{l}\text { Admiralty Inlet - } \\
\text { Puget Sound, } \\
\text { United States }\end{array}$ & Tidal turbine & $\begin{array}{l}\text { 95th percentile operating condition for the } \\
\text { OpenHydro turbine was used in this } \\
\text { laboratory experience--sound pressure level } \\
\text { (SPL) of } 159 \mathrm{~dB} \text { re } 1 \mu \mathrm{Pa} \text {, which corresponds to } \\
\text { the source level (nominal received level at } 1 \mathrm{~m} \\
\text { from the sound source). }\end{array}$ & $\begin{array}{l}\text { Conducted laboratory exposure experiments of } \\
\text { juvenile Chinook salmon and showed that exposure } \\
\text { to a worse than worst case acoustic dose of turbine } \\
\text { sound did not result in changes to hearing } \\
\text { thresholds or biologically significant tissue damage. } \\
\text { Collectively, this means that Chinook salmon may } \\
\text { be at a relatively low risk of injury from sound } \\
\text { produced by tidal turbines located in or near their } \\
\text { migration path. Study showed that harbor porpoise } \\
\text { in the area may be habituated to high levels of } \\
\text { ambient noise due to omnipresent vessel traffic. }\end{array}$ & N/A \\
\hline $\begin{array}{c}\text { WaveRoller } \\
\text { (2012-2014) [49] }\end{array}$ & $\begin{array}{c}\text { WavEc- } \\
\text { Peniche, Portugal }\end{array}$ & WEC & $\begin{array}{c}\text { Operational noise of bottom-mounted } \\
\text { oscillating wave surge converter prototype } \\
\text { peaked at } 121 \mathrm{~dB} \text { re } 1 \mu \mathrm{Pa} \text {. } \\
\text { Average broadband SPL measured with } \\
\text { Hydrophone } 2 \text { varied between } 115 \text { and } 126 \mathrm{~dB} \\
\text { re } 1 \mu \text { Pa rms and with } \\
\text { Hydrophone } 1 \text { between } 115 \text { and } 121 \mathrm{~dB} \text { re } \\
1 \mu \mathrm{Pa} \text { rms. } \\
\text { SPL values decreased over time. The noise } \\
\text { decreased within } 300 \mathrm{~m} \text { of the device. }\end{array}$ & $\begin{array}{l}\text { Calculating the sound exposure level (SEL) of the } \\
\text { WaveRoller sound, which was } 150 \mathrm{~dB} \mathrm{re} 1 \mu \mathrm{Pa}^{2} / \mathrm{s} \text {, } \\
\text { showed that no injury to cetaceans is expected. The } \\
\text { results indicated that the frequency ranges at which } \\
\text { the device operates overlap those used by some low } \\
\text { and midfrequency cetaceans, but only behavioral } \\
\text { responses would be expected if the organisms swim } \\
\text { near the WaveRoller. Additionally, no cetaceans } \\
\text { were around the WaveRoller device, likely due to } \\
\text { the low depth where the device was installed. }\end{array}$ & $\begin{array}{l}\text { Remains under } \\
\text { threshold for } \\
\text { broadband sound }\end{array}$ \\
\hline
\end{tabular}


Table 1. Cont.

\begin{tabular}{|c|c|c|c|c|c|}
\hline Project & Location & Device & Noise Measurements & Conclusion & $\begin{array}{c}\text { Relation to U.S. } \\
\text { Underwater } \\
\text { Sound Threshold }\end{array}$ \\
\hline $\begin{array}{l}\text { EDF and DCNS } \\
\text { Energies OpenHydro, } \\
(2013-2014)[50]\end{array}$ & $\begin{array}{l}\text { Paimpol Brehat, } \\
\text { France }\end{array}$ & Tidal turbine & $\begin{array}{l}\text { SPL ranged from } 118 \text { to } 152 \mathrm{~dB} \text { re } 1 \mu \mathrm{Pa} \text { at } 1 \mathrm{~m} \\
\text { in third-octave bands at frequencies between } \\
40 \text { and } 8192 \mathrm{~Hz} \text {, which were measured at } \\
\text { distances between } 100-2400 \mathrm{~m} \text { from the } \\
\text { turbine. The acoustic footprint of the device } \\
\text { corresponds to a } 1.5 \mathrm{~km} \text { radius disk. }\end{array}$ & $\begin{array}{l}\text { Physiological injury of marine mammals, fish, and } \\
\text { invertebrates was improbable within the area of } \\
\text { greatest potential impact. Permanent threshold } \\
\text { shifts (PTS) and temporary threshold shifts (TTS) } \\
\text { risks were non-existent for all target species. } \\
\text { Behavioral } \\
\text { disturbance may occur up to } 1 \mathrm{~km} \text { around the } \\
\text { device for harbor porpoises only, but is of little } \\
\text { concern for a single turbine. }\end{array}$ & $\begin{array}{l}\text { Remains under } \\
\text { threshold for } \\
\text { broadband sound }\end{array}$ \\
\hline $\begin{array}{l}\text { Schottel instream tidal } \\
\text { turbine, (2014) [47] }\end{array}$ & $\begin{array}{l}\text { Strangford Lough, } \\
\text { Northern Ireland }\end{array}$ & Tidal turbine & $\begin{array}{l}\text { Highest noise levels were around } 100 \text { re } \\
\mu \mathrm{Pa}^{2} / \mathrm{Hz} \text { at } 9 \mathrm{~m} \text { from the turbine. }\end{array}$ & $\begin{array}{l}\text { Sounds levels were on the same order as natural and } \\
\text { anthropogenic background noise measured. }\end{array}$ & N/A \\
\hline $\begin{array}{c}\text { ORPC Cobscook Bay } \\
\text { Tidal Energy Project } \\
(2013-2017)[72]\end{array}$ & $\begin{array}{c}\text { Maine, } \\
\text { United States }\end{array}$ & Tidal turbine & $\begin{array}{l}\text { Operational noise less than } 100 \mathrm{~dB} \mathrm{re} \mu \mathrm{Pa}^{2} / \mathrm{Hz} \\
\text { at } 10 \mathrm{~m} \text {, at } 200-500 \mathrm{~m} \text { from the turbine. }\end{array}$ & $\begin{array}{c}\text { Sound was not detectable above ambient } \\
\text { noise levels. }\end{array}$ & $\mathrm{N} / \mathrm{A}$ \\
\hline $\begin{array}{l}\text { Minesto AB Tidal Kite, } \\
\text { (2016) [51] }\end{array}$ & $\begin{array}{c}\text { Strangford } \\
\text { Narrows, } \\
\text { Northern Ireland }\end{array}$ & Tidal kite & $\begin{array}{l}\text { Sound levels for the one-quarter scale tidal } \\
\text { kite tested at different speeds ranging from } 70 \\
\mathrm{~dB} \text { re } \mu \mathrm{Pa} \text { at the lowest frequencies up to a } \\
\text { peak of around } 105 \mathrm{~dB} \text { re } \mu \mathrm{Pa} \text { at } 500 \mathrm{~Hz} \text {. }\end{array}$ & $\begin{array}{l}\text { Sound levels remained below thresholds for marine } \\
\text { mammals and fish. }\end{array}$ & $\begin{array}{l}\text { Remains under } \\
\text { threshold for } \\
\text { broadband sound }\end{array}$ \\
\hline $\begin{array}{l}\text { Fred. Olsen Bolt } \\
\text { Lifesaver, } \\
(2016-2018) \text { [53] }\end{array}$ & $\begin{array}{l}\text { U.S. Navy Wave } \\
\text { Energy Test Site } \\
\text { (WETS) - O'ahu, } \\
\text { United States }\end{array}$ & WEC & $\begin{array}{l}\text { Operational noise of floating point absorber } \\
\text { wave device was } 114 \mathrm{~dB} \text { re } 1 \mu \mathrm{Pa} \text { for median } \\
\text { broadband SPL, and mean levels as high as } \\
159 \mathrm{~dB} \text { re } 1 \mu \mathrm{Pa} \text { were infrequently observed. } \\
\text { At one point during the study, the WEC had a } \\
\text { damaged bearing, which coupled with the } \\
\text { operational noise reached } 124 \mathrm{~dB} \text { re } 1 \mu \mathrm{Pa} \text {. }\end{array}$ & $\begin{array}{l}\text { Operational noise levels remained below acceptable } \\
\text { thresholds. Received levels exceeded the U.S. } \\
\text { regulatory threshold for auditory harassment of } \\
\text { marine mammals (broadband level of } 120 \mathrm{~dB} \text { re } \\
1 \mu \mathrm{Pa} \text { ) for only } 1 \% \text { of the deployment. These } \\
\text { exceedance events were dominated by } \\
\text { non-propagating flow noise and sources unrelated } \\
\text { to the Lifesaver. }\end{array}$ & $\begin{array}{l}\text { Operational } \\
\text { sounds from } \\
\text { device remain } \\
\text { under threshold } \\
\text { for broadband } \\
\text { sound }\end{array}$ \\
\hline $\begin{array}{c}\text { Wello Oy } \\
(2017-2019)[48]\end{array}$ & $\begin{array}{l}\text { European Marine } \\
\text { Energy Centre } \\
\text { (EMEC) - } \\
\text { Orkney, } \\
\text { United Kingdom }\end{array}$ & WEC & $\begin{array}{l}\text { The measured sound pressure levels of this } \\
\text { floating rotating mass WEC's cooling system, } \\
\text { which included two cooling fans and one } \\
\text { pump, suggested a source level of } 140.5 \mathrm{~dB} \text { re } \\
1 \mu \mathrm{Pa} \text { at } 1 \mathrm{~m} \text {. }\end{array}$ & $\begin{array}{l}\text { Expected that ambient background noise levels will } \\
\text { be reached within about } 10 \mathrm{~m} \text { of the device. }\end{array}$ & $\begin{array}{l}\text { Remains under } \\
\text { threshold for } \\
\text { broadband sound }\end{array}$ \\
\hline
\end{tabular}


Table 2. Comparison of U.S. regulatory thresholds for marine mammals and fish for comparison with underwater noise measurements at the MRE project sites

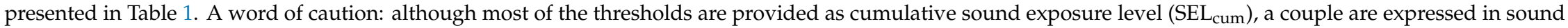
pressure level (SPL) and root mean square (RMS), and measurements at MRE project sites were expressed in a diversity of units (e.g., source level, source pressure level, sound pressure spectrum level) and direct comparison with the thresholds should be avoided (see [73] for a conversion tool).

\begin{tabular}{|c|c|c|c|}
\hline \multirow[b]{2}{*}{ Source } & \multirow[b]{2}{*}{ Measurement } & \multicolumn{2}{|c|}{ Animals of Interest } \\
\hline & & Marine Mammals & Fishes \\
\hline \multirow{5}{*}{ NMFS (2018)—temporary threshold shifts (TTS) } & $179 \mathrm{~dB}$ re $1 \mu \mathrm{Pa}^{2} / \mathrm{s}\left(\mathrm{SEL}_{\text {cum }}\right)$ & Low-frequency cetaceans & \\
\hline & $178 \mathrm{re} 1 \mu \mathrm{Pa}^{2} / \mathrm{s}\left(\mathrm{SEL}_{\text {cum }}\right)$ & Mid-frequency cetaceans & \\
\hline & $153 \mathrm{re} 1 \mu \mathrm{Pa}^{2} / \mathrm{s}\left(\mathrm{SEL}_{\text {cum }}\right)$ & High-frequency cetaceans & \\
\hline & $181 \mathrm{re} 1 \mu \mathrm{Pa}^{2} / \mathrm{s}\left(\mathrm{SEL}_{\text {cum }}\right)$ & Phocid pinnipeds & \\
\hline & 199 re $1 \mu \mathrm{Pa}^{2} / \mathrm{s}\left(\mathrm{SE}_{\text {cum }}\right)$ & Otariid pinnipeds & \\
\hline \multirow{3}{*}{ Tetra Tech Inc. (2013) — physiological effects thresholds } & $206 \mathrm{~dB}$ re $1 \mu \mathrm{Pa}(\mathrm{SPL})$ & & Fish—absolute peak \\
\hline & $187 \mathrm{~dB}$ re $1 \mu \mathrm{Pa}^{2} / \mathrm{s}\left(\mathrm{SEL}_{\text {cum }}\right)$ & & Fish $>2 \mathrm{~g}$ \\
\hline & $183 \mathrm{~dB}$ re $1 \mu \mathrm{Pa}^{2} / \mathrm{s}\left(\mathrm{SEL}_{\text {cum }}\right)$ & & Fish $<2 \mathrm{~g}$ \\
\hline Tetra Tech Inc. (2013)—behavioral effects thresholds & $150 \mathrm{~dB}$ re $1 \mu \mathrm{Pa}(\mathrm{RMS})$ & & Absolute \\
\hline Verdant Power Roosevelt Island Tidal Energy Project & $\leq 145 \mathrm{~dB}$ re $1 \mu \mathrm{Pa}$ at $1 \mathrm{~m}$ & & $\mathrm{x}$ \\
\hline Columbia Power Technologies SeaRay & $116-126 \mathrm{~dB}$ re $1 \mu \mathrm{Pa}^{2}$ & $\mathrm{x}$ & $\mathrm{x}$ \\
\hline OpenHydro at Admiralty Inlet (playback study) & $\leq 159 \mathrm{~dB}$ re $1 \mu \mathrm{Pa}$ at $1 \mathrm{~m}$ & $\mathrm{x}$ & $\mathrm{x}$ \\
\hline WaveRoller at WavEc & $115-126 \mathrm{~dB}$ re $1 \mu \mathrm{Pa}$ & $\mathrm{x}$ & \\
\hline EDF and DCNS Energies OpenHydro & $118-152 \mathrm{~dB}$ re $1 \mu \mathrm{Pa}$ at $1 \mathrm{~m}$ & $\mathrm{x}$ & $\mathrm{x}$ \\
\hline Schottel instream tidal turbine & $\leq 100 \mathrm{~dB}$ re $\mu \mathrm{Pa}^{2} / \mathrm{Hz}$ at $9 \mathrm{~m}$ & $\mathrm{x}$ & \\
\hline ORPC Cobscook Bay Tidal Energy Project & $\leq 100 \mathrm{~dB}$ re $\mu \mathrm{Pa}^{2} / \mathrm{Hz}$ at $10 \mathrm{~m}$ & & $\mathrm{x}$ \\
\hline Minesto AB Tidal Kite & $70-105 \mathrm{~dB}$ re $\mu \mathrm{Pa}$ & $\mathrm{x}$ & $\mathrm{x}$ \\
\hline Fred. Olsen Bolt Lifesaver at WETS & $114-159 \mathrm{~dB}$ re $1 \mu \mathrm{Pa}$ & $\mathrm{x}$ & \\
\hline Wello Oy at EMEC & $\leq 140.5 \mathrm{~dB}$ re $1 \mu \mathrm{Pa}$ at $1 \mathrm{~m}$ & $\mathrm{x}$ & \\
\hline
\end{tabular}


Table 3. Selected studies from the evidence base for electromagnetic field (EMF) effects on marine animals. These outcomes are based on research studies that examined undersea cables and surrogates associated with energized power cables, telecommunications cables, and other electrical infrastructure. In the absence of a regulatory threshold, the measured or modeled level of EMF cannot be used directly to determine whether harm may occur for consenting processes.

\begin{tabular}{|c|c|c|c|c|}
\hline Project/Research Study & Location & Cable or EMF Source & EMF Measurements & Conclusion \\
\hline $\begin{array}{l}\text { Sub-Sea Power Cables And The } \\
\text { Migration Behaviour Of The } \\
\text { European Eel (2008) [54] }\end{array}$ & East Sweden & $\begin{array}{l}130 \mathrm{kV} \text { AC cable, } \\
\text { unburied. }\end{array}$ & $\begin{array}{l}\text { Acoustic tags were used to track small } \\
\text { movements across energized cable. }\end{array}$ & $\begin{array}{c}\text { Eels swam more slowly, but effect was not significant and } \\
\text { no evidence of barrier effect. }\end{array}$ \\
\hline $\begin{array}{c}\text { EMF-Sensitive Fish Response to EM } \\
\text { Emissions from Sub-Sea Electricity } \\
\text { Cables of the Type Used by the } \\
\text { Offshore Renewable Energy Industry } \\
\text { (2009) [55] }\end{array}$ & $\begin{array}{c}\text { West } \\
\text { Scotland }\end{array}$ & $\begin{array}{l}125 \mathrm{kV} \text { AC cable, } \\
\text { buried } 0.5-1 \mathrm{~m} \text { deep. }\end{array}$ & $\begin{array}{l}\text { Mesocosms were used with both energized } \\
\text { and control cables. }\end{array}$ & $\begin{array}{l}\text { No evidence of significant positive or negative effect on } \\
\text { catsharks (dogfish). Benthic skates responded to EMF } \\
\text { in cable. }\end{array}$ \\
\hline $\begin{array}{l}\text { Effects of Electromagnetic Fields on } \\
\text { Fish and Invertebrates [58] }\end{array}$ & N/A & $\begin{array}{l}\text { Helmholz coil in } \\
\text { laboratory }\end{array}$ & $\begin{array}{l}\text { Assessed the response of coho salmon, } \\
\text { Atlantic halibut, California halibut, } \\
\text { Dungeness crab, and American lobster to } \\
\text { elevated EMF at } 3 \mathrm{mT}(3000 \mu \mathrm{T}) \text {. }\end{array}$ & $\begin{array}{l}\text { No significant evidence to indicate distinct or extreme } \\
\text { behavioral responses. Several developmental and } \\
\text { physiological responses were observed in the fish } \\
\text { exposures, although most were not statistically significant } \\
\text { Several movement and activity responses were observed } \\
\text { in the crab experiments. There may be possible } \\
\text { developmental and behavioral responses even to small } \\
\text { environmental effects; however, further replication is } \\
\text { needed in the laboratory as well as field verification. }\end{array}$ \\
\hline $\begin{array}{l}\text { Effects of Electromagnetic Fields on } \\
\text { Fish and Invertebrates [60] }\end{array}$ & N/A & $\begin{array}{l}\text { Helmholz coil in } \\
\text { laboratory }\end{array}$ & $\begin{array}{l}\text { Assessed response of Atlantic halibut, } \\
\text { Dungeness crab, and American lobster to } \\
\text { maximum EMF strength between 1.0-1.2 mT } \\
\text { direct current DC. }\end{array}$ & $\begin{array}{l}\text { On the basis of the initial laboratory screening studies, the } \\
\text { weight of evidence to date for the three tested species } \\
\text { showed relatively few behavioral responses that would } \\
\text { indicate explicit avoidance or attraction to an approximate } \\
1.1 \text { mT DC EMF intensity. }\end{array}$ \\
\hline $\begin{array}{c}\text { Effects of Electromagnetic Fields on } \\
\text { Behavior of Largemouth Bass and } \\
\text { Pallid Sturgeon in an Experimental } \\
\text { Pond Setting [65] }\end{array}$ & N/A & $\begin{array}{l}\text { Energized cable in } \\
\text { pond }\end{array}$ & $\begin{array}{l}\text { Assessed movements of largemouth bass and } \\
\text { pallid sturgeon in mesocosm experiments in } \\
\text { a freshwater pond. Fish experienced } \\
\text { alternating } 2 \mathrm{~h} \text { periods in which an } \\
\text { underwater energized AC coil was } \\
\text { alternately powered on and off }(2450 \mu \mathrm{T}) \text {. }\end{array}$ & $\begin{array}{l}\text { No consistent significant differences in location or activity } \\
\text { relative to the location of the coil for largemouth bass and } \\
\text { pallid sturgeon as a result of exposure to EMF. }\end{array}$ \\
\hline $\begin{array}{l}\text { MaRVEN - Environmental Impacts of } \\
\text { Noise, Vibrations and } \\
\text { Electromagnetic Emissions from } \\
\text { Marine Renewable Energy (2015) [12] }\end{array}$ & $\begin{array}{l}\text { North Sea, } \\
\text { Belgium }\end{array}$ & $\begin{array}{l}\text { AC cables (infield and } \\
\text { export), buried } \\
1.0-1.05 \mathrm{~m} \text { deep. }\end{array}$ & $\begin{array}{l}\text { Measured EMF from offshore wind turbine } \\
\text { and export cables during power generation } \\
\text { through drifting and sledge towing. }\end{array}$ & $\begin{array}{l}\text { EMF from wind turbine was considerably weaker than } \\
\text { EMF from export cables to shore. The electric fields from } \\
\text { the AC cables were within the range of detection by } \\
\text { sensitive receptor species, but the magnetic field emitted } \\
\text { was at the lower end, potentially outside the detectable } \\
\text { range. EMF at biologically relevant levels can be observed. }\end{array}$ \\
\hline
\end{tabular}


Table 3. Cont

\begin{tabular}{|c|c|c|c|c|}
\hline Project/Research Study & Location & Cable or EMF Source & EMF Measurements & Conclusion \\
\hline $\begin{array}{l}\text { Limited Influence of a Wind Power } \\
\text { Project Submarine Cable on a } \\
\text { Laurentian Great Lakes Fish } \\
\text { Community (2015) [66] }\end{array}$ & $\begin{array}{l}\text { Kingston, } \\
\text { Canada }\end{array}$ & $\begin{array}{c}245 \mathrm{kV} \text { AC cable, } \\
\text { buried (nearshore } \\
\text { section) and unburied. }\end{array}$ & $\begin{array}{l}\text { Nearshore electrofishing and deeper water } \\
\text { fisheries acoustic surveys performed along } \\
\text { transects at varying distances to the cable. }\end{array}$ & EMF impacts to species are likely minimal. \\
\hline $\begin{array}{l}\text { Assessment of Potential Impacts of } \\
\text { Electromagnetic Fields from } \\
\text { Undersea Cable on Migratory Fish } \\
\text { Behavior (2016) [67] }\end{array}$ & $\begin{array}{l}\text { San Francisco } \\
\text { Bay, } \\
\text { United States }\end{array}$ & $\begin{array}{l}200 \text { kV DC cable, } \\
\text { buried. }\end{array}$ & $\begin{array}{l}\text { Tagged fish to track movement and used } \\
\text { magnetometer surveys to measure EMF. }\end{array}$ & $\begin{array}{l}\text { Fish (green and white sturgeon, salmon, steelhead smolt) } \\
\text { did not appear to be affected. There were large magnetic } \\
\text { signatures from bridges and other infrastructure that the } \\
\text { cable could not be distinguished from. }\end{array}$ \\
\hline $\begin{array}{l}\text { Renewable Energy In Situ Power } \\
\text { Cable Observation (2016) [68] }\end{array}$ & $\begin{array}{l}\text { California, } \\
\text { United States }\end{array}$ & $\begin{array}{l}35 \mathrm{kV} \text { AC power } \\
\text { transmission cable, } \\
\text { buried. }\end{array}$ & $\begin{array}{c}\text { Surveyed marine life along an existing pipe, } \\
\text { cable, and sandy bottom (control). Placed } \\
\text { transects along each. }\end{array}$ & $\begin{array}{l}\text { No response from fish or macroinvertebrates to EMF. Did } \\
\text { not find any biologically significant differences among fish } \\
\text { and invertebrate communities between pipe, energized } \\
\text { cable, and sandy bottom. EMF produced by the energized } \\
\text { cables diminished to background levels about } 1 \text { m away } \\
\text { from the cable. }\end{array}$ \\
\hline $\begin{array}{l}\text { Assessing Potential Impacts of } \\
\text { Energized Submarine Power Cables } \\
\text { on Crab Harvests (2017) [63] }\end{array}$ & $\begin{array}{l}\text { Santa Barbara } \\
\text { channel and } \\
\text { Puget Sound, } \\
\text { United States }\end{array}$ & $\begin{array}{l}35 \mathrm{kV} \text { AC power cable, } \\
\text { unburied (Santa } \\
\text { Barbara, California), } \\
\text { and } 69 \mathrm{kV} \text { AC power } \\
\text { cable, unburied (Puget } \\
\text { Sound, Washington). }\end{array}$ & $\begin{array}{l}\text { Four test conditions with baited } \\
\text { commercial traps. }\end{array}$ & $\begin{array}{l}\text { Both rock crab (Santa Barbara) and Dungeness crab } \\
\text { (Puget Sound) crossed unburied cable to traps. }\end{array}$ \\
\hline $\begin{array}{l}\text { Electromagnetic Field (EMF) Impacts } \\
\text { on Elasmobranch (Shark, Rays, and } \\
\text { Skates) and American Lobster } \\
\text { Movement and Migration from Direct } \\
\text { Current Cables (2018) [64] }\end{array}$ & $\begin{array}{l}\text { Northeast } \\
\text { United States }\end{array}$ & 300 kV DC, buried. & $\begin{array}{l}\text { Employed an enclosure with animals using } \\
\text { acoustic telemetry tags and variable power } \\
\qquad(0,100 \text {, and } 330 \mathrm{MW})\end{array}$ & $\begin{array}{l}\text { American lobster had a statistically significant, but subtle } \\
\text { change in behavior in response to EMF, and Little skate } \\
\text { had a statistically significant behavioral response to EMF } \\
\text { from cable, but the EMF from the cable did not act as a } \\
\text { barrier to movement for either species. }\end{array}$ \\
\hline $\begin{array}{l}\text { Behavioral Responses by Migrating } \\
\text { Juvenile Salmonids to a Subsea } \\
\text { High-Voltage DC Power Cable } \\
\text { (2018) [69] }\end{array}$ & $\begin{array}{l}\text { San Francisco } \\
\text { Bay, } \\
\text { United States }\end{array}$ & $\begin{array}{l}200 \mathrm{kV} \text { DC cable, } \\
\text { buried. }\end{array}$ & $\begin{array}{l}\text { Tagged Chinook salmon smolts and tracked } \\
\text { movement both before and after energization } \\
\text { of Trans Bay Cable. }\end{array}$ & $\begin{array}{l}\text { Smolts successfully migrated through the bay before and } \\
\text { after cable energization without significant differences, } \\
\text { and energization was not associated with crossing the } \\
\text { cable (or successfully exiting the system). }\end{array}$ \\
\hline $\begin{array}{l}\text { Effects of EMF Emissions from } \\
\text { Undersea Electric Cables on Coral } \\
\text { Reef Fish (2018) [70] }\end{array}$ & $\begin{array}{l}\text { Florida, } \\
\text { United States }\end{array}$ & $\begin{array}{l}\text { AC ( } 60 \mathrm{~Hz} \text { cable) and } \\
\text { DC cable, unburied. }\end{array}$ & $\begin{array}{l}\text { Used blind randomized sequences of AC ( } 60 \\
\text { Hz cable) and DC cable off (ambient) or on } \\
\text { (energized) with in situ observations of fish } \\
\text { abundance and behavior. }\end{array}$ & $\begin{array}{l}\text { No behavioral changes noted in immediate response to } \\
\text { alterations in EMF and no statistical differences in fish } \\
\text { abundance among power states. }\end{array}$ \\
\hline
\end{tabular}


Table 3. Cont

\begin{tabular}{|c|c|c|c|c|}
\hline Project/Research Study & Location & Cable or EMF Source & EMF Measurements & Conclusion \\
\hline $\begin{array}{c}\text { Effect of Low Frequency } \\
\text { Electromagnetic Field on the Behavior } \\
\text { and Bioenergetics of the Polychaete } \\
\text { Hediste diversicolor (2019) [74] }\end{array}$ & N/A & $\begin{array}{c}\text { Two Helmholz coils in } \\
\text { laboratory }\end{array}$ & $\begin{array}{l}\text { Assessed the effect of an EMF of value } \\
\text { typically recorded in the vicinity of } \\
\text { submarine cables }(50 \mathrm{~Hz}, 1 \mathrm{mT}) \text { on the } \\
\text { behavior and bioenergetics of the polychaete } \\
\text { Hediste diversicolor. }\end{array}$ & $\begin{array}{l}\text { No avoidance or attraction behavior to EMF was shown. } \\
\text { Food consumption and respiration rates were not affected. } \\
\text { The burrowing activity was enhanced in EMF treatment, } \\
\text { indicating a stimulating effect on bioturbation potential, } \\
\text { and ammonia excretion rate was significantly reduced in } \\
\text { EMF treatment, but the mechanisms behind this effect } \\
\text { were unclear. This is the first study demonstrating the } \\
\text { effects of environmentally realistic EMF values on the } \\
\text { behavior and physiology of marine invertebrates, thus } \\
\text { there is a need for more research. }\end{array}$ \\
\hline
\end{tabular}




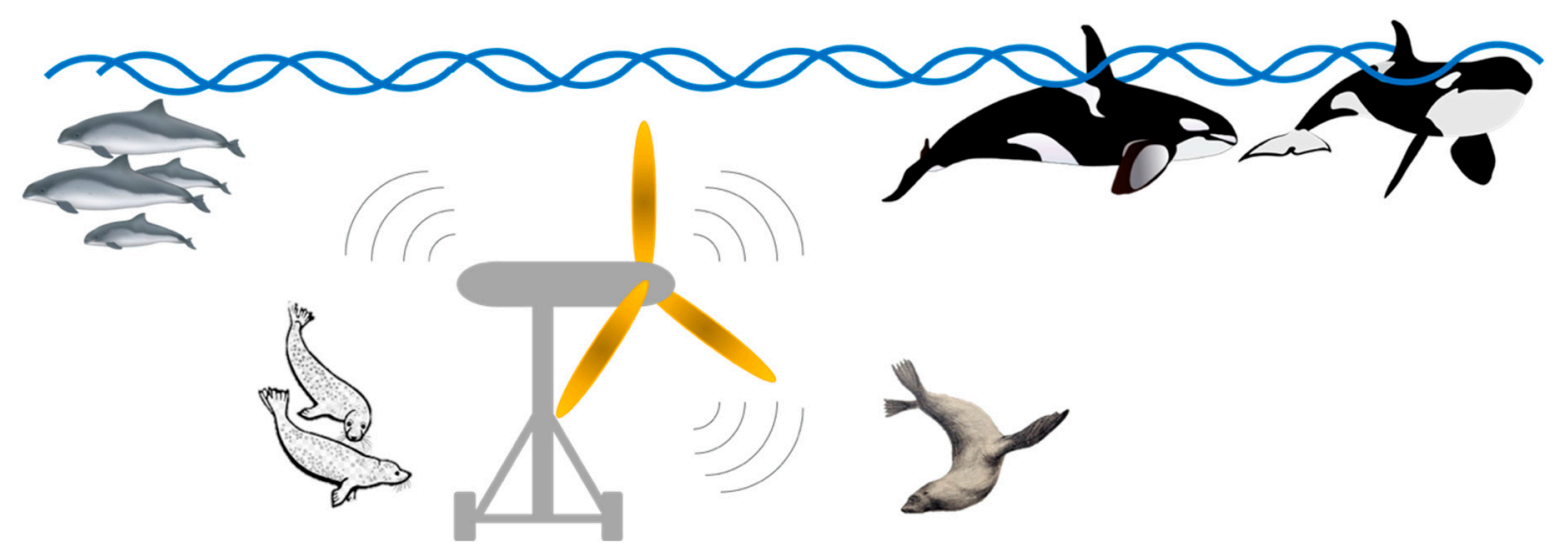

Figure 3. Hypothetical example presented at one of the international workshops, with a tidal turbine emitting a realistic level of underwater noise in an area used by harbor porpoises, harbor seals, sea lions, and killer whales.

\subsubsection{Risk Retirement for Underwater Noise}

There was consensus at all three workshops that underwater noise could be retired for small numbers of devices. The experts felt that there were some outstanding information needs to ensure that the risk of underwater noise was sufficiently understood:

(1) The underwater sound output should be measured for each new MRE technology (or an existing technology planned for a new location), following the standard procedures developed by the International Electrical Commission's Technical Committee 114 Technical Specification 62600-40 [45], in order to ensure that these outputs fall under the U.S. regulatory thresholds [43] across the frequency spectra (see Table 2). However, some nations may require different standards, although none could be found codified in statute or regulation.

(2) Some experts and practitioners felt there is still a need to understand how animals use the surrounding area of the device to determine if the sound from an MRE device might change their behavior.

(3) Test centers should be encouraged to work with MRE developers to measure the sound output from their devices.

(4) Moving from single (or small numbers of) devices, the spacing of devices may need to be regulated to avoid increased propagation of sound over larger distances.

(5) Sound propagation models need to be verified to ensure they are fit for the high-energy, high-turbulence, and often high-turbidity areas where MRE devices are deployed, in order to help predict noise effects of future commercial developments.

\subsubsection{Risk Retirement for EMF}

The evidence base for EMF was examined at two of the workshops (Italy and Australia). The participants felt that EMF from cables carrying power to shore or draped in the water column between devices are not likely to be a risk for small numbers of MRE devices. They arrived at this conclusion in part due to the fact that the level of power carried in MRE cables is many times lower than that carried by offshore wind power export cables, or by electrical cables that convey grid power from mainlands to offshore islands in many parts of the world. There was also consensus around the burial of cables (where feasible) as a means to alleviate concerns and protect sensitive species. There were some additional information needs raised:

(1) There is no accessible database of EMF emissions by specific sizes and types of cables appropriate for MRE development. This data collection should be encouraged, as it will assist developers and regulators in rapidly assessing likely EMF outputs and risks. 
(2) Baseline data are needed to determine the electro- or magneto-sensitive species likely to be in an area of an MRE development, and the manner in which these species use the habitats close to MRE cables.

(3) As the MRE industry grows commercially, there will be a need to examine the cumulative effects of EMF from many power cables, in addition to the additive nature of EMF with other cables in a region.

(4) The lack of a regulatory threshold or standard for underwater EMF emissions found anywhere in the world places an additional challenge on regulators to determine what level of EMF may be considered safe in the marine environment.

(5) Although the risk is likely to be very small, field measurements of EMF may be needed around most MRE developments to assuage stakeholder concerns.

\section{Discussion}

Although the knowledge base of environmental effects of MRE with the marine environment continues to grow, there are still serious gaps in understanding the mechanisms that may cause harm to marine animals and habitats, as well as a need for greater certainty in the emerging cause and effect relationships [14]. Equally important is the need to make what is known accessible to regulators and other stakeholders. Unless this refinement of the stressor-receptor interactions around MRE is carried out, the status quo of few annual deployments will continue. Without greater numbers of devices in the water, many questions surrounding stressor-receptor interactions cannot be investigated, and the same low level of uncertainty will remain [31].

The slow but steady expansion of MRE development around the world results in greater numbers of regulators who become involved in MRE device consenting and who will need to understand their potential effects. This need can be addressed by organizing and making accessible all available knowledge, a goal that is met by open access online information compilations such as Tethys (https://tethys.pnnl.gov), and by finding a path forward for risk retirement. Involving experts and MRE practitioners, gathering extensive input on the risk retirement process, and applying it to specific MRE stressors will allow the overall MRE community to bring their collective expertise and experience to bear on the problem.

In the course of engaging regulators and other stakeholders in the risk retirement and data transferability processes, it appears that some regulators and stakeholders believe that studies and monitoring data collected in one waterbody or jurisdiction are not applicable to other locations, specifically to the waterbody in which they have an interest. Although the unique properties, including the presence of specific species and habitats, of each location into which an MRE device is placed must be acknowledged, many of the basic mechanisms of interaction are common among locations and indigenous species. Understanding these common mechanisms will allow the risk retirement process and application for specific stressors to advance. It is, however, important to recognize that the collection of some site-specific data for baseline and post-installation monitoring assessment will always be required for new projects, in order to validate the mechanisms and to add to the growing knowledge base.

Potential effects of underwater noise from MRE devices is a universal concern that is raised by regulators and other stakeholders, and is based on a lack of understanding of how marine animal behavior might be affected $[40,41]$. This concern has led to calls for animal behavior studies in the vicinity of operational MRE devices. Unfortunately, animal behavior studies, particularly in underwater regions with strong currents or waves, are technically challenging, extremely costly, and hard to interpret, particularly as animals become acclimatized to the stressor or change their behavior in other ways [75]. The concerns expressed by stakeholders are largely based on impacts from other industries such as seismic seafloor exploration and commercial shipping [76]. The regulatory thresholds that were developed to regulate these and other maritime industries [30] provide a basis for identifying MRE underwater noise as unlikely to cause harm. Relying on data from operational MRE devices, measured 
under an international standard for data collection methods and measurements [32], in conjunction with the regulatory thresholds, provides a useful path forward for retiring this risk. The ease with which underwater noise data can be collected, as an element of monitoring carried out to measure the health of the device, makes this risk one that can be examined over the life of a device or array, and allows for a high degree of certainty that this risk can be better understood over time.

Concerns around EMF have been raised increasingly throughout the MRE and offshore wind industry progression [57]. Despite the presence of many electricity-bearing cables in the oceans for over a century, this is a relatively new issue of concern that has been raised in the marine domain [77]. Without any standards or regulatory thresholds, EMF risk from MRE cables must be addressed through a growing research base, comparisons with cables carrying electricity for other industries, and laboratory studies that indicate the risk to not be significant [77]. The present evidence base appears to be sufficient to determine that for the low power modes generated by single MRE devices, the risk to susceptible marine animals is very low.

The experience with examining risk retirement for underwater noise and EMF paves the way for a similar process to be readily carried out for two other stressors associated with the presence and operation of small numbers of MRE devices: changes in benthic and pelagic habitats and changes in physical oceanographic systems. Changes in habitats from MRE development is likely to be a manageable risk as the footprint on the seafloor or in the water column is relatively small [78], and the risks can easily be informed and evaluated on the basis of extensive knowledge of effects from other industries such as oil and gas operations at sea [79], presence of offshore wind towers and platforms [80], effects of cable laying [48], and a wide range of fishing activities. Changes in physical oceanographic systems can be realized by changing water flow around a bottom-mounted or floating turbine, as well as decreasing wave heights and other effects of removing energy from ocean water in the form of MRE generation [81-83]. However, the natural variability of the systems is much higher than could possibly be measured for small numbers of devices [84]. Until large MRE arrays are in place, hydrodynamic models provide the best estimates of what changes might occur in the oceanographic regime, and eventually translate into changes in water quality or ecosystem dynamics. On the basis of numerical outputs of these models, no changes are likely to be measurable until very large numbers of devices are deployed and operated [85].

\section{Conclusions}

The risk retirement pathway developed for OES-Environmental has been viewed by regulators, researchers, developers, and other stakeholders through webinars, in-person meetings, and workshops. To date, the experts and practitioners have been cautiously optimistic and have encouraged continued development of this work. A summary of the evidence for risk retirement for underwater noise and EMF for small numbers of MRE devices was presented in this paper. This evidence base has been scrutinized by 81 experts and practitioners in 11 countries and has generally been accepted as reasonable proof of what is known about these interactions worldwide. The outcome of the assessments has determined that recent measurements of underwater noise from MRE devices and their potential effect on marine mammals and fish indicate that the amplitude of the sound from an MRE device likely falls under U.S. regulatory thresholds for underwater noise across the frequency spectrum. As such, for small numbers of devices, the experts and practitioners felt that the risk could be retired, on the basis of the acquisition of measurements of underwater noise for each new MRE device. Similarly, the experts and practitioners felt that the evidence base for EMF indicates that the field and laboratory studies of EMF from cables appear to be at levels below which marine animals living in the vicinity are likely to be harmed, allowing this risk also to be retired.

Moving forward with this work, the authors and their collaborators in OES-Environmental and the wider MRE community intend to assess the risk retirement potential for small numbers of MRE devices for changes in benthic and pelagic habitats and for changes in the physical oceanographic systems. At the same time, the very challenging stressor-receptor interaction of animals around 
operating turbines for risk of collision will be addressed. This work will help reduce the uncertainty around potential environmental effects of single devices and, eventually, inform the risk from larger commercial arrays of MRE devices using the outcome and growing knowledge base gained from examining small numbers of devices.

Supplementary Materials: The following are available online at http://www.mdpi.com/2077-1312/8/3/172/s1, Figure S1: Risk retirement pathway. Starting on the left, the project must be described (orange circle), followed by identifying the presence of animals or habitats that may be at risk (purple circle). Five stage gates follow that allow retirement of risk at each stage. The dotted lines and arrows above indicate the transferability of datasets from previously consented projects and research studies that inform each step in the process and create feedback loops. Figure S2: Relationship of the four components that make up the data transferability process. Table S1: Data collection consistency table, listing methods for data collection, reporting units, and analysis. Table S2: Best management practices for data transferability, including the purpose of each BMP and the interested parties who would benefit from their use.

Author Contributions: Conceptualization, A.E.C.; methodology, A.E.C., M.C.F. and A.M.G.; data curation, A.E.C., M.C.F. and L.G.H.; writing-original draft preparation, A.E.C., M.C.F., A.M.G. and L.G.H.; writing-review and editing, A.E.C., M.C.F., A.M.G. and L.G.H.; project administration, A.M.G.; funding acquisition, A.E.C. All authors have read and agreed to the published version of the manuscript.

Funding: This research has been made possible due to the generous financial support of the U.S. Department of Energy, Energy Efficiency and Renewable Energy Water Power Technologies Office to Pacific Northwest National Laboratory under contract DE-AC05-76RL01830 to Pacific Northwest National Laboratory, as well as financial support from the International Energy Agency-Ocean Energy Systems.

Acknowledgments: We appreciate the support and collaboration of the 14 other OES-Environmental nations and their representatives, including their guidance, feedback, and insight. We would also like to thank the regulators and other experts of the MRE community who participated in our survey and workshops and helped us refine our approach and provide feedback throughout the process. We wish to thank Pacific Northwest National Laboratory staff who have contributed to this work: Jonathan Whiting, Lysel Garavelli, Hayley Farr, Dorian Overhus, Deborah Rose, Levy Tugade, Cailene Gunn, and Matthew Sturtevant. We are grateful for the ongoing support and guidance from the U.S. Department of Energy, Water Power Technologies Office, and the collaboration with U.S. Department of Energy staff, including Samantha Eaves, Hoyt Battey, and Tim Ramsey.

Conflicts of Interest: The authors declare no conflict of interest. The funders had no role in the design of the study; in the collection, analyses, or interpretation of data; in the writing of the manuscript; or in the decision to publish the results.

\section{References}

1. United Nations General Assembly. Report on the Work of the United Nations Open-Ended Informal Consultative Process on Oceans and the Law of the Sea at Its Thirteenth Meeting. 2012, p. 14. Available online: https: //www.un.org/Depts/los/consultative_process/icp13_panellist_table.pdf (accessed on 3 January 2020).

2. Wright, G. Strengthening the role of science in marine governance through environmental impact assessment: A case study of the marine renewable energy industry. Ocean Coast. Manag. 2014, 99, 23-30. [CrossRef]

3. Copping, A.; Sather, N.; Hanna, L.; Whiting, J.; Zydlewski, G.; Staines, G.; Gill, A.; Hutchison, I.; O’Hagan, A.; Simas, T.; et al. Annex IV 2016 State of the Science Report: Environmental Effects of Marine Renewable Energy Development around the World. April 2016; p. 224. Available online: https://tethys.pnnl.gov/ publications/state-of-the-science-2016 (accessed on 3 January 2020).

4. IRENA. Renewable Energy Statistics 2019; The International Renewable Energy Agency: Abu Dhabi, UAE, 2019; p. 398.

5. Blanco Ilzarbe, J.M.; Teixeira, J.A. Recent Patents on Tidal Power Extraction Devices. Recent Patents Eng. 2009, 3, 178-193. [CrossRef]

6. Lopez, I.; Andreu, J.; Ceballos, S.; Martinez de Alegria, I.; Kortabarria, I. Review of wave energy technologies and the necessary power-equipment. Renew. Sustain. Energy Rev. 2013, 27, 413-434. [CrossRef]

7. O'Hagan, A. Consenting Processes for Ocean Energy: Update on Barriers and Recommendations; MaREI Centre: Cork, Ireland, 2016; p. 40.

8. Willsteed, E.; Gill, A.B.; Birchenough, S.N.R.; Jude, S. Assessing the cumulative environmental effects of marine renewable energy developments: Establishing common ground. Sci. Total Environ. 2017, 577, 9-32. [CrossRef] [PubMed] 
9. Lin, L.; Yu, H. Offshore Wave Energy Generation Devices: Impacts on Ocean Bio-Environment. Acta Ecol. Sin. 2012, 32, 117-122. [CrossRef]

10. Norris, J.; Cowan, D.; Bristow, C.; Magagna, D.; Giebhardt, J. D4.7 Best Practice Report on Environmental Monitoring and New Study Techniques. In Marine Renewables Infrastructure Network for Emerging Energy Technologies (MARINET); 2014; p. 105. Available online: https://tethys.pnnl.gov/publications/d47-bestpractice-report-environmental-monitoring-new-study-techniques (accessed on 3 January 2020).

11. Gibbs, M.T.; Browman, H.I. Risk assessment and risk management: A primer for marine scientists. ICES J. Mar. Sci. 2015, 72, 992-996. [CrossRef]

12. Thomsen, F.; Gill, A.; Kosecka, M.; Andersson, M.; Andre, M.; Degraer, S.; Folegot, T.; Gabriel, J.; Judd, A.; Neumann, T.; et al. MaRVEN-Environmental Impacts of Noise, Vibrations and Electromagnetic Emissions from Marine Renewable Energy_Final Study Report; DG RTD (Directorate-General for Research and Innovation of the European Commission): Luxembourg, 2015; p. 81.

13. Conn, P.; Silber, G. Vessel speed restrictions reduce risk of collision-related mortality for North Atlantic right whales. Ecosphere 2013, 4, 1-16. [CrossRef]

14. Dannheim, J.; Bergström, L.; Birchenough, S.; Brzana, R.; Boon, A.; Coolen, J.; Degraer, S. Benthic effects of offshore renewables: Identification of knowledge gaps and urgently needed research. ICES J. Mar. Sci. 2019. [CrossRef]

15. Gill, A.B. Offshore renewable energy: Ecological implications of generating electricity in the coastal zone. J. Appl. Ecol. 2005, 42, 605-615. [CrossRef]

16. Boehlert, G.W.; Gill, A.B. Environmental and Ecological Effects of Ocean Renewable Energy Development: A Current Synthesis. Oceanography 2010, 23, 68-81. [CrossRef]

17. MeyGen. Lessons Learnt from MeyGen Phase 1a Part 1/3: Design Phase. MEY-1A-70-REP-010-F Lessons Learned Design Phase. 2017; p. 15. Available online: https://www.google.com.hk/url?sa=t\&rct=j\&q=\&esrc=s\&source= web\&cd=1\&cad=rja\&uact=8\&ved=2ahUKEwjtyruBlIDoAhXRBogKHfZmAUkQFjAAegQIBhAC\&url=https $\%$ 3A\%2F\%2Ftethys.pnnl.gov\%2Fsites\%2Fdefault\%2Ffiles\%2Fpublications\%2FMeyGen-2017-Part1.pdf\&usg= AOvVaw1-g2OJmDj0Tiaz8CW-v56J (accessed on 3 January 2020).

18. Marine Scotland. Survey, Deploy and Monitor Licensing Policy Guidance. 2016; p. 11. Available online: https://www2.gov.scot/Topics/marine/Licensing/marine/Applications/SDM (accessed on 3 January 2020).

19. Caine, C.A. The place of the Rochdale envelope approach in offshore renewable energy. Environ. Law Rev. 2018, 20, 74-88. [CrossRef]

20. The Planning Inspectorate. Using the Rochdale Envelope. 2018; p. 8. Available online: https://tethys.pnnl. gov/publications/using-rochdale-envelope (accessed on 3 January 2020).

21. Le Lièvre, C. Sustainably reconciling offshore renewable energy with Natura 2000 sites: An interim adaptive management framework. Energy Policy 2019, 129, 491-501. [CrossRef]

22. Cormier, R.; Stelzenmuller, V.; Creed, I.; Igras, J.; Rambo, H.; Callies, U.; Johnson, L. The science-policy interface of risk-based freshwater and marine management systems: From concepts to practical tools. J. Environ. Manag. 2018, 226, 340-346. [CrossRef] [PubMed]

23. Hobday, A.; Smith, A.; Stobutzki, I.; Bulman, C.; Daley, R.; Dambacher, J.; Deng, R.; Dowdney, J.; Fuller, M.; Furlani, D.; et al. Ecological risk assessment for the effects of fishing. Fish. Res. 2011, 108, 372-384. [CrossRef]

24. Anderson, R.M.; Copping, A.E.; Van Cleve, F.B. Environmental Risk Evaluation System (ERES) for Offshore Wind-Mock-Up of ERES, Fiscal Year 2010 Progress Report; PNNL-20020; Pacific Northwest National Lab (PNNL): Richland, WA, USA, 2010; p. 68.

25. Copping, A.; Hanna, L.; Van Cleve, B.; Blake, K.; Anderson, R. Environmental Risk Evaluation System-an Approach to Ranking Risk of Ocean Energy Development on Coastal and Estuarine Environments. Estuaries Coasts 2015, 38, 287-302. [CrossRef]

26. The Scottish Government. Impact Assessment Tool. Available online: http://www.marine-impact.co.uk/ (accessed on 3 January 2020).

27. Stelzenmüller, V.; Coll, M.; Mazaris, A.D.; Giakoumi, S.; Katsanevakis, S.; Portman, M.E.; Degen, R.; Mackelworth, P.; Gimpel, A.; Albano, P.G.; et al. A risk-based approach to cumulative effect assessments for marine management. Sci. Total Environ. 2018, 612, 1132-1140. [CrossRef]

28. ICES. Workshop on Cumulative Effects Assessment Approaches in Management (WKCEAM). ICES Sci. Rep. 2019,33 . 
29. Korpinen, S.; Andersen, J. A Global Review of Cumulative Pressure and Impact Assessments in Marine Environments. Front. Mar. Sci. 2016, 3, 153. [CrossRef]

30. Tamis, J.E.; de Vries, P.; Jongbloed, R.H.; Lagerveld, S.; Jak, R.G.; Karman, C.C.; Van der Wal, J.T.; Slijkerman, D.M.; Klok, C. Toward a harmonized approach for environmental assessment of human activities in the marine environment. Integr. Environ. Assess. Manag. 2016, 12, 632-642. [CrossRef]

31. Copping, A. The State of Knowledge for Environmental Effects: Driving Consenting/Permitting for the Marine Renewable Energy Industry; Pacific Northwest National Laboratory: Richland, WA, USA, 2018; p. 25.

32. Copping, A.; Battey, H.; Brown-Saracino, J.; Massaua, M.; Smith, C. An international assessment of the environmental effects of marine energy development. Ocean Coast. Manag. 2014, 99, 3-13. [CrossRef]

33. National Academies of Sciences, Engineering, and Medicine. Guidelines for Managing Geotechnical Risks in Design Build Projects 2018; The National Academies Press: Washington, DC, USA, 2018.

34. Copping, A.; Hanna, L.; Whiting, J.; Geerlofs, S.; Grear, M.; Blake, K.; Coffey, A.; Massaua, M.; Brown-Saracino, J.; Battey, H. Environmental Effects of Marine Energy Development around the World: Annex IV Final Report; Pacific Northwest National Laboratory: Richland, WA, USA, 2013; p. 96.

35. Copping, A.; Freeman, M.; Overhus, D. Risk Retirement for Environmental Effects of Marine Renewable Energy; Pacific Northwest National Laboratory: Richland, WA, USA, 2020.

36. Copping, A.; Freeman, M.; Gorton, A. Retiring Environmental Risks: Facilitating Marine Renewable Energy Development through Accelerated Consenting. In Proceedings of the 13th European Wave and Tidal Energy Conference, Napoli, Italy, 1-6 September 2019; p. 6.

37. Copping, A.; Gorton, A.; Freeman, M.; Rose, D.; Farr, H. Data Transferability and Collection Consistency in Marine Renewable Energy: An Update to the 2018 Report; PNNL-27995; Pacific Northwest National Laboratory: Richland, WA, USA, 2020.

38. Copping, A.; Hemery, L. OES-Environmental 2020 State of the Science Report: Environmental Effects of Marine Renewable Energy Development around the World. in press. Available online: https:/tethys.pnnl. gov/about-oes-environmental (accessed on 3 January 2020).

39. Dreyer, S. MRE Regulator Survey Report; Pacific Northwest National Laboratory: Richland, WA, USA, 2017; p. 21.

40. Clark, C.W.; Ellison, W.; Southall, B.; Hatch, L.; Van Parijs, S.; Frankel, A.; Ponirakis, D. Acoustic masking in marine ecosystems: Intuitions, analysis, and implication. Mar. Ecol. Prog. Ser. 2009, 395, 201-222. [CrossRef]

41. OSPAR Commission. Overview of The Impacts of Anthropogenic Underwater Sound in the Marine Environment. 2009; p. 134. Available online: https:/tethys.pnnl.gov/publications/overview-impactsanthropogenic-underwater-sound-marine-environment (accessed on 3 January 2020).

42. Wilson, B.; Batty, R.; Daunt, F.; Carter, C. Collision Risks Between Marine Renewable Energy Devices and Mammals, Fish and Diving Birds; Scottish Association for Marine Science: Oban, Scotland, 2007; p. 110.

43. NMFS. 2018 Revisions to: Technical Guidance for Assessing the Effects of Anthropogenic Sound on Marine Mammal Hearing (Version 2.0): Underwater Thresholds for Onset of Permanent and Temporary Threshold Shifts; National Oceanic Atmospheric Administration Technical Memorandum NMFS-OPR-59; National Oceanic Atmospheric Administration: Silver Spring, MD, USA, 2018; p. 178.

44. Tetra Tech Inc. Underwater Acoustic Modeling Report-Virginia Offshore Wind Technology Advancement Project (VOWTAP). 2013; p. 47. Available online: https://tethys.pnnl.gov/publications/underwater-acousticmodeling-report-virginia-offshore-wind-technology-advancement (accessed on 3 January 2020).

45. International Electrotechnical Commission. TC 114: Marine Energy-Wave, Tidal and Other Water Current Converters. 2019. Available online: https://www.iec.ch/dyn/www/f?p=103:22:0::::FSP_ORG_ID:1316 (accessed on 3 January 2020).

46. Bassett, C.; Thomson, J.; Polagye, B.; Rhinefrank, K. Underwater noise measurements of a 1/7th scale wave energy converter. In Proceedings of the 2011 MTS/IEEE Oceans Conference, Waikoloa, HI, USA, 19-22 September 2011; pp. 1-6.

47. Schmitt, P.; Elsaesser, B.; Coffin, M.; Hood, J.; Starzmann, R. Field testing a full-scale tidal turbine part 3: Acoustic characteristics. In Proceedings of the European Wave and Tidal Energy Conference, Nantes, France, 6-11 September 2015.

48. Beharie, R.; Side, J. Acoustic Environmental Monitoring-Wello Penguin Cooling System Noise Study; 2012/01/AQ; International Centre for Island Technology: Orkney, Scotland, 2012; p. 22. 
49. Cruz, E.; Simas, T.; Kasanen, E. Discussion of the Effects of the Underwater Noise Radiated by a Wave Energy Device-Portugal. In Proceedings of the 11th European Wave and Tidal Energy Conference, Nantes, France, 6-11 September 2015; p. 5.

50. Lossent, J.; Lejart, M.; Folegot, T.; Clorennec, D.; Di Iorio, L.; Gervaise, C. Underwater operational noise level emitted by a tidal current turbine and its potential impact on marine fauna. Mar. Pollut. Bull. 2018, 131, 323-334. [CrossRef] [PubMed]

51. Schmitt, P.; Pine, M.K.; Culloch, R.M.; Lieber, L.; Kregting, L.T. Noise characterization of a subsea tidal kite. J. Acoust. Soc. Am. 2018, 144, EL441-EL446. [CrossRef] [PubMed]

52. Verdant Power. RITE Project Kinetic Hydropower Pilot License Application. Volume 2: FERC Exhibit E Environmental Report and Exhibit G Project Boundary Map. Part 1: Application; Proposed Action and Alternatives; Consultation and Compliance; Environmental Analysis, Geology and Soils, Water Resources, Aquatic Resources. 2010, p. 123. Available online: https://www.verdantpower.com/rite (accessed on 3 January 2020).

53. Polagye, B.; Murphy, P.; Cross, P.; Vega, L. Acoustic Characteristics of the Lifesaver Wave Energy Converter. In Proceedings of the 12th European Wave and Tidal Energy Conference (EWTEC), Cork, Ireland, 27 August-1 September 2017.

54. Westerberg, H.; Lagenfelt, I. Sub-sea power cables and the migration behaviour of the European eel. Fish. Manag. Ecol. 2008, 15, 369-375. [CrossRef]

55. Gill, A.; Huang, Y.; Gloyne-Philips, I.; Metcalfe, J.; Quayle, V.; Spencer, J.; Wearmouth, V. COWRIE 2.0 Electromagnetic Fields (EMF) Phase 2: EMF Sensitive Fish Response to EM Emissions from Sub-Sea Electricity Cables of the Type Used by the Offshore Renewable Energy Industry. 2009; p. 128. Available online: https://tethys.pnnl.gov/publications/cowrie-20-electromagnetic-fields-emf-phase-2-emf-sensitivefish-response-em-emissions (accessed on 3 January 2020).

56. Woodruff, D.L.; Ward, J.A.; Schultz, I.R.; Cullinan, V.I.; Marshall, K.E. Effects of Electromagnetic Fields on Fish and Invertebrates. Task 2.1.3: Effects on Aquatic Organisms. Fiscal Year 2011 Progress Report on the Environmental Effects of Marine and Hydrokinetic Energy; PNNL-20813; Pacific Northwest National Laboratory: Richland, WA, USA, 2012.

57. Gill, A.; Kimber, J.; Sigray, P. Marine Renewable Energy, Electromagnetic (EM) Fields and EM-Sensitive Animals. In Marine Renewable Energy Technology and Environmental Interactions; Shields, M.P.A., Ed.; Springer: Dordrecht, The Netherlands, 2014; pp. 61-79.

58. Schultz, I.; Woodruff, D.; Marshall, K.; Pratt, W.; Roesijadi, G. Effects of Electromagnetic Fields on Fish and Invertebrates_Fiscal Year 2010 Progress Report; Pacific Northwest National Laboratory: Richland, WA, USA, 2010; p. 26.

59. Kavet, R.W.M.; Klimley, A.P. Modeling Magnetic Fields from a DC Power Cable Buried Beneath San Francisco Bay Based on Empirical Measurements. PLoS ONE 2016, 11. [CrossRef]

60. Woodruff, D.; Cullinan, V.; Copping, A.; Marshall, K. Effects of Electromagnetic Fields on Fish and Invertebrates_FY2012 Progress Report; PNNL-22154; Pacific Northwest National Laboratory: Richland, WA, USA, 2013; p. 62.

61. Taormina, B. Potential Impacts of Submarine Power Cables from Marine Renewable Energy Projects on Benthic Communities. Ph.D. Thesis, University of Western Brittany, Brest, France, 2019.

62. Fey, D.; Jakubowska, M.; Greszkiewicz, M.; Andrulewicz, E.; Otremba, Z.; Urban-Malinga, B. Are magnetic and electromagnetic fields of anthropogenic origin potential threats to early life stages of fish? Aquat. Toxicol. 2019, 209, 150-158. [CrossRef]

63. Love, M.S.; Nishimoto, M.M.; Clark, S.; McCrea, M.; Bull, A.S. Assessing potential impacts of energized submarine power cables on crab harvests. Cont. Shelf Res. 2017, 151, 23-29. [CrossRef]

64. Hutchison, Z.; Sigray, P.; He, H.; Gill, A.; King, J.; Gibson, C. Electromagnetic Field (EMF) Impacts on Elasmobranch (Shark, Rays, and Skates) and American Lobster Movement and Migration from Direct Current Cables; OCS Study BOEM 2018-003; U.S. Department of the Interior, Bureau of Ocean Energy Management: Sterling, VA, USA, 2018; p. 254.

65. Bevelhimer, M.S.; Cada, G.F.; Scherelis, C. Effects of Electromagnetic Fields on Behavior of Largemouth Bass and Pallid Sturgeon in an Experimental Pond Setting. Oak Ridge National Laboratory, 2015; p. 23. Available online: https://tethys.pnnl.gov/publications/effects-electromagnetic-fields-behavior-largemouthbass-pallid-sturgeon-experimental (accessed on 3 January 2020). 
66. Dunlop, E.S.; Reid, S.M.; Murrant, M. Limited influence of a wind power project submarine cable on a Laurentian Great Lakes fish community. J. Appl. Ichthyol. 2016, 32, 18-31. [CrossRef]

67. Kavet, R.; Wyman, M.; Klimley, A.; Vergara, X. Assessment of Potential Impact of Electromagnetic Fields from Undersea Cable on Migratory Fish Behavior. Electric Power Research Institute, 2016; p. 89. Available online: https:/tethys.pnnl.gov/publications/assessment-potential-impact-electromagnetic-fields-underseacable-migratory-fish (accessed on 3 January 2020).

68. Love, M.; Nishimoto, M.; Clark, S.; Bull, A. Renewable Energy In Situ Power Cable Observation; OCS Study BOEM 2016-008; University of California Santa Barbara: Camarillo, CA, USA, 2016; p. 106.

69. Wyman, M.T.; Peter Klimley, A.; Battleson, R.D.; Agosta, T.V.; Chapman, E.D.; Haverkamp, P.J.; Pagel, M.D.; Kavet, R. Behavioral responses by migrating juvenile salmonids to a subsea high-voltage DC power cable. Mar. Biol. 2018, 165. [CrossRef]

70. Kilfoyle, A.K.; Jermain, R.F.; Dhanak, M.R.; Huston, J.P.; Spieler, R.E. Effects of EMF emissions from undersea electric cables on coral reef fish. Bioelectromagnetics 2018, 39, 35-52. [CrossRef] [PubMed]

71. Collar, C.; Spahr, J.; Polagye, B.; Thomson, J.; Bassett, C.; Graber, J.; Cavagnaro, R.; Talbert, J.; deKlerk, A.; Reay-Ellers, A.; et al. Study of the Acoustic Effects of Hydrokinetic Tidal Turbine in Admiralty Inlet, Puget Sound. 2012; p. 80. Available online: https://tethys.pnnl.gov/publications/study-acoustic-effectshydrokinetic-tidal-turbine-admiralty-inlet-puget-sound (accessed on 3 January 2020).

72. ORPC Maine. Cobscook Bay Tidal Energy Project, 2013 Environmental Monitoring Report Final Draft; Portland. 2014. Available online: https:/tethys.pnnl.gov/publications/cobscook-bay-tidal-energy-project2013-environmental-monitoring-report (accessed on 3 January 2020).

73. Ren, H.; Halvorsen, M.; Deng, Z.; Carlson, T. Aquatic acoustic metrics interface utility for underwater sound monitoring and analysis. Sensors 2012, 12, 7438-7450. [CrossRef] [PubMed]

74. Jakubowska, M.; Urban-Malinga, B.; Otremba, Z.; Andrulewicz, E. Effect of low frequency electromagnetic field on the behavior and bioenergetics of the polychaete Hediste diversicolor. Mar. Environ. Res. 2019, 150. [CrossRef] [PubMed]

75. Robertson, F.; Wood, J.; Joslin, J.; Joy, R.; Polagye, B. Marine Mammal Behavioral Response to Tidal Turbine Sound, Final Technical Report for DE-EE0006385. 2018. Available online: https:/tethys.pnnl.gov/researchstudies/marine-mammal-behavioral-response-tidal-turbine-sound (accessed on 3 January 2020).

76. Scholik-Schlomer, A. Where the Decibels Hit the Water: Perspectives on the Application of Science to Real-World Underwater Noise and Marine Protected Species Issues. Acoust. Today 2015, 11, 36-44.

77. Taormina, B.; Bald, J.; Want, A.; Thouzeau, G.; Lejart, M.; Desroy, N.; Carlier, A. A review of potential impacts of submarine power cables on the marine environment: Knowledge gaps, recommendations and future directions. Renew. Sustain. Energy Rev. 2018, 96, 380-391. [CrossRef]

78. Iglesias, G.; Tercero, J.; Simas, T.; Machado, I.; Cruz, E. Wave and Tidal Energy: Environmental Effects. In Wave and Tidal Energy; Greaves, D., Iglesias, G., Eds.; John Wiley \& Sons Ltd.: West Sussex, UK, 2018; pp. 346-454.

79. Page, H.M.; Dugan, J.E.; Dugan, D.S.; Richards, J.B.; Hubbard, D.M. Effects of an offshore oil platform on the distribution and abundance of commercially important crab species. Mar. Ecol. Prog. Ser. 1999, 185, 47-57. [CrossRef]

80. Lindeboom, H.; Degraer, S.; Dannheim, J.; Gill, A.B.; Wilhelmsson, D. Offshore wind park monitoring programmes, lessons learned and recommendations for the future. Hydrobiologia 2015, 756, 169-180. [CrossRef]

81. Chang, G.; Magalen, J.; Jones, C.; Roberts, J. Wave Energy Converter Effects on Wave Fields: Evaluation of SNL-SWAN and Sensitivity Studies in Monterey Bay, CA; Sandia National Laboratories report SAND2014-17460; Sandia National Laboratories: Albuquerque, NM, USA; Livermore, CA, USA, 2014; p. 76.

82. De Dominicis, M.; Murray, R.; Wolf, J. Multi-Scale Ocean Response to a Large Tidal Stream Turbine Array. Renew. Energy 2017, 114, 1160-1179. [CrossRef]

83. Neill, S.; Robins, P.; Fairley, I. The Impact of Marine Renewable Energy Extraction on Sediment Dynamics. In Marine Renewable Energy; Springer: Cham, Switzerland, 2017; pp. 279-304. 
84. Shields, M.; Woolf, D.; Grist, E.; Kerr, S.; Jackson, A.; Harris, R.; Bell, M.; Beharie, R.; Want, A.; Osalusi, E.; et al. Marine Renewable Energy: The Ecological Implications of Altering the Hydrodynamics of the Marine Environment. Ocean Coast. Manag. 2011, 54, 2-9. [CrossRef]

85. Van der Molen, J.; Ruardij, P.; Greenwood, N. Potential Environmental Impact of Tidal Energy Extraction in the Pentland Firth at Large Spatial Scales: Results of a Biogeochemical Model. Biogeosciences 2016, 13, 2593-2609. [CrossRef]

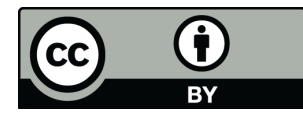

(C) 2020 by the authors. Licensee MDPI, Basel, Switzerland. This article is an open access article distributed under the terms and conditions of the Creative Commons Attribution (CC BY) license (http://creativecommons.org/licenses/by/4.0/). 